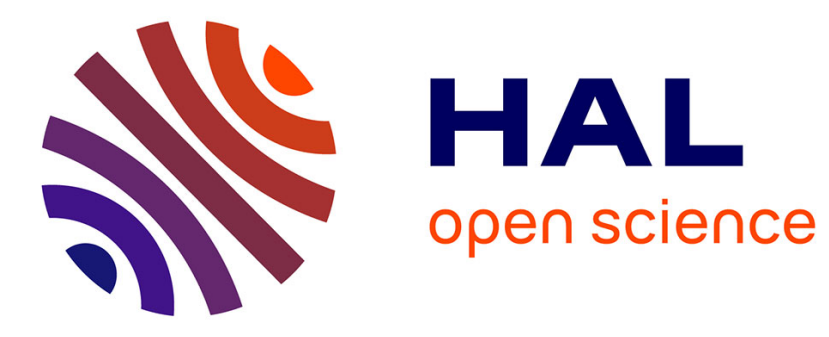

\title{
Does off-trail backcountry skiing disturb moose?
}

\author{
Wiebke Neumann, Göran Ericsson, Holger Dettki
}

\section{To cite this version:}

Wiebke Neumann, Göran Ericsson, Holger Dettki. Does off-trail backcountry skiing disturb moose? European Journal of Wildlife Research, 2009, 56 (4), pp.513-518. 10.1007/s10344-009-0340-x . hal00612972

\section{HAL Id: hal-00612972 \\ https://hal.science/hal-00612972}

Submitted on 2 Aug 2011

HAL is a multi-disciplinary open access archive for the deposit and dissemination of scientific research documents, whether they are published or not. The documents may come from teaching and research institutions in France or abroad, or from public or private research centers.
L'archive ouverte pluridisciplinaire HAL, est destinée au dépôt et à la diffusion de documents scientifiques de niveau recherche, publiés ou non, émanant des établissements d'enseignement et de recherche français ou étrangers, des laboratoires publics ou privés. 


\title{
Does off-trail backcountry skiing disturb moose?
}

\author{
Wiebke Neumann • Göran Ericsson • Holger Dettki
}

Received: 30 June 2009 /Revised: 16 October 2009 / Accepted: 20 October 2009 /Published online: 10 November 2009

(C) Springer-Verlag 2009

\begin{abstract}
The advancement of recreational activities into wildlife habitat calls for a better knowledge about the effects of human-induced disturbances, particularly in systems where humans dominate wildlife mortality. We exposed nine adult free-ranging female moose repeatedly to off-trail backcountry skiing to study moose behavior and habituation using a controlled field experiment in Northern Sweden. Moose response was short-term, but distinct. Moose moved 33-fold faster during the first hour following disturbance, resulting in almost a doubling of the energetic usage per kilogram body weight. Movement rates increased $3 \mathrm{~h}$ following disturbances, came along with enlarged activity ranges at the day of disturbance, and resulted in moose leaving the original area. We found no evidence for habituation. Because of the short-term response, the effect of single skiing disturbance events on the overall energy budget of large-bodied animals in good body condition is likely to be negligible. We recommend off-trail skiers to avoid following wildlife tracks because such disturbances bear risk for more severe consequences on wildlife's energy budget if wildlife resists habituation, if an animal's risk perception is high, or when the frequency of disturbance increases.
\end{abstract}

\footnotetext{
Communicated by W. Lutz

W. Neumann $(\triangle) \cdot$ G. Ericsson $\cdot$ H. Dettki

Department of Wildlife, Fish, and Environmental Studies,

Swedish University of Agricultural Sciences,

SE-901 83 Umeå, Sweden

e-mail: Wiebke.Neumann@vfm.slu.se

G. Ericsson

e-mail: Goran.Ericsson@vfm.slu.se

H. Dettki

e-mail: Holger.Dettki@vfm.slu.se
}

Keywords Experimental disturbances · Human impact . Individual-based analysis $\cdot$ Alces alces $\cdot$ Sweden

\section{Introduction}

Human recreational activities expand increasingly into wildlife habitat, becoming a part of wildlife's environment (Ingold 2005; Knight and Gutzwiller 1995; Stankowich 2008). Human-induced disturbances may affect wildlife ecology because they may trigger a behavioral response analog to predation risk, generating similar behavioral costs (Picton 1999; Frid and Dill 2002; Fortin and Andruskiw 2003; Reimers et al. 2003; Taylor and Knight 2003). In areas where human harvest accounts for the major source of wildlife mortality, the impact of human activity on wildlife is of particular interest (e.g., Ericsson and Wallin 2001; Lima 1992; Solberg et al. 2000). Antipredator behaviors are complex (Liley and Creel 2008). Predation risk affects animals not only directly, but also indirectly by changing animal's behavior such as their spatial organization, resulting in the "landscape of fear" and causing trophic cascades (Berger 2007; Brown and Kotler 2007; Creel and Christianson 2007). Compared to on-trail activity, the unpredictable temporal and spatial character of off-trail activities often result in a larger influence zone (Taylor and Knight 2003; Stankowich 2008). In Northern Europe, off-trail activities such as backcountry skiing, hiking, and snowmobile driving are popular recreational activities. Besides the type of disturbance, animal's activity prior disturbance, relative location to the origin of disturbance, and topographic features further influence the level of disturbance (Cassirer et al. 1992; Reimers et al. 2003; Stankowich 2008).

However, animals that do not relocate in the presence of disturbance may not imply undisturbed wildlife, but a lack of 
alternative habitats to switch to (Gill et al. 2001). Like predation risk, human disturbances can cause increased levels of stress affecting physiological parameters (Creel et al. 2002). Impact on physiological conditions such as increased stress levels or movement activity caused by disturbance may bear severe consequences for wildlife that range in seasonal environments and that must handle conservative energy management strategies (Schwartz and Renecker 2007). Locomotion costs vary with animal size and ground cover, and smaller animals such as, e.g., moose calves face relatively greater locomotion costs, especially when moving in snow (Coady 1974; Fancy and White 1985).

Using a controlled field experiment and state-of-the-art Global Positioning System (GPS) technology, we studied the impact of off-trail backcountry skiing activity with following up of moose tracks on moose behavior. The degree of habituation may vary among individuals in a population (Picton 1999; Stankowich 2008). Thus, we applied individual-based behavioral analyses to test for habituation using moose movement rates, i.e., "speed" (in meters per hour), as a proxy and analyzed moose daily activity ranges to address the impact on moose spatial organization.

Based on theory and previous research, we predict that disturbance by off-trail backcountry skiing would be reflected by (1) an increase in moose average movement rates, (2) an increase in moose diurnal activity area, and (3) disturbance would result in a spatial reorganization of moose, i.e., moose activity ranges would overlap less after disturbance than before. Based on humans being the predominant source of moose mortality in our study area, we also predicted that (4) moose would not habituate to the repeated, but unpredictable, human-induced disturbance stimuli. In addition, we estimated the metabolic costs associated with the predicted increased movement rates for adults and potentially following moose calves.

\section{Material and methods}

We collected GPS location data from nine adult free-ranging female moose during March 6-11 in 2006. Moose ranged between the inland boreal forests to the low alpine areas in Northern Sweden with an average moose density of around 0.3 individuals per square kilometer, excluding the areas above tree line (Fig. 1). During winter, moose ranged in the inland forest $\left(64^{\circ} 26^{\prime} \mathrm{N}, 19^{\circ} 22^{\prime} \mathrm{E}\right.$; WGS84) that is dominated by monocultures of Scots pine Pinus sylvestris covering a gently rolled landscape with an average elevation of $309 \mathrm{~m} \pm 87$ standard deviation (SD). Human density is moderate with an average of 6.0 humans per square kilometer and $1.0 \mathrm{~km}$ road per square kilometer (Statistics Sweden 2008; Swedish Land Survey 2008). With the start of the vegetation period, moose migrate to the low alpine area $\left(65^{\circ} 42^{\prime} \mathrm{N}, 16^{\circ} 46^{\prime} \mathrm{E}\right.$; WGS84)

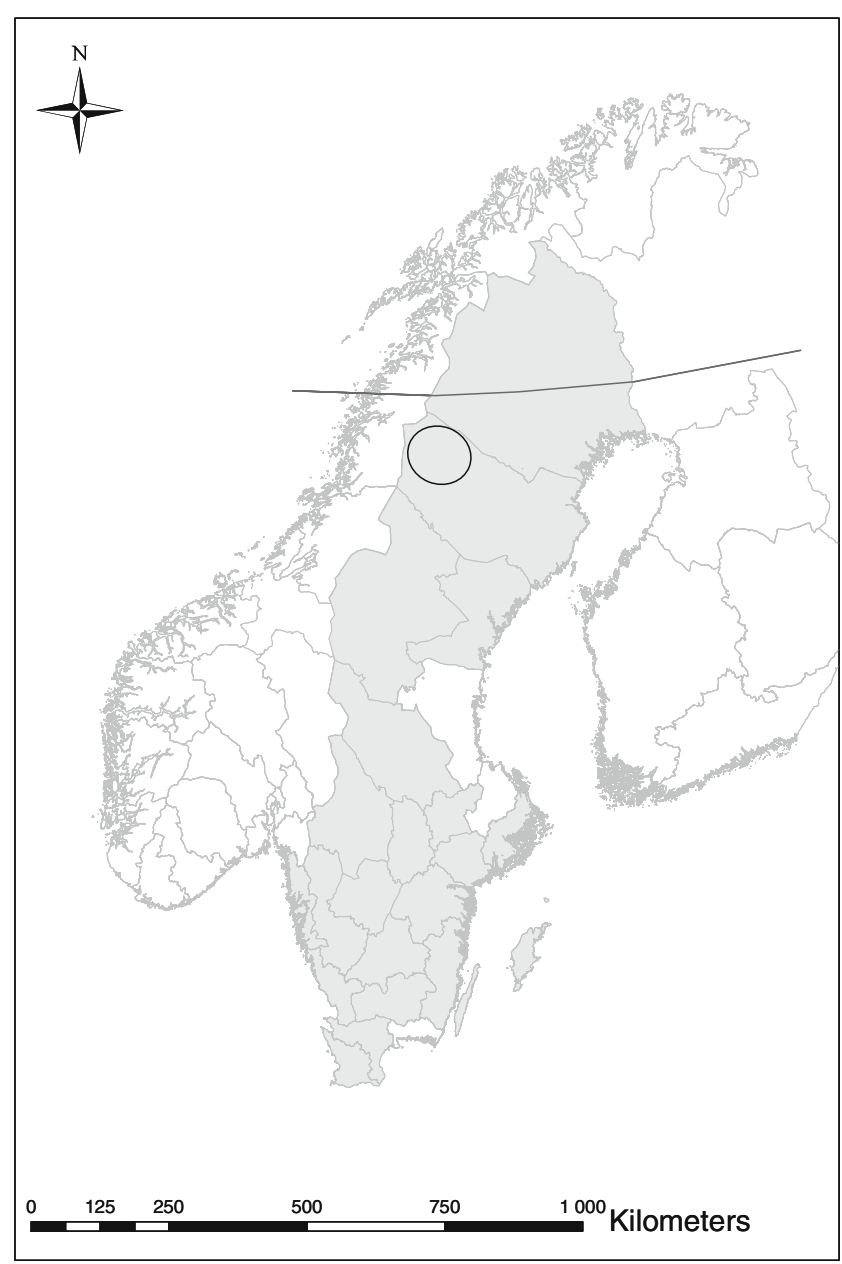

Fig. 1 Map of Fennoscandia with Sweden marked in gray. The study area is represented by the solid circle, representing a gradient from low alpine environments to inland boreal forest from west to east. The Arctic Circle is indicated by a line

that consists of boreal and mountainous forest, partly above tree line, with an average elevation of $996 \mathrm{~m} \pm 424 \mathrm{SD}$, low human density ( 0.9 humans per square kilometer; Statistics Sweden 2008) and relatively low accessibility $(0.4 \mathrm{~km}$ road per square kilometer; Swedish Land Survey 2008).

Swedish moose populations experience a sustained hunting pressure with hunting as the major source of moose mortality that accounts for $81 \%$ of mortality in female moose (Ericsson and Wallin 2001; Lavsund and Sandegren 1989; Swedish AHWM 2009). In contrast, the mortality risk from natural predators is low, particularly for adult moose (Swedish EPA 2008; Swenson et al. 2007).

\section{Moose disturbances}

We immobilized moose from a helicopter using a dart gun to inject a mixture of an anesthetic and a tranquilizer (etorphine and xylazine; Arnemo et al. 2006). We equipped each female with a collar that included a GPS receiver, 
Global System for Mobile (GSM) communication modem, and a traditional very high frequency (VHF) beacon (Vectronic Aerospace GmbH, Berlin, Germany). The GPS collars calculated a position at least every $30 \mathrm{~min}$. The GPS collar sent the information onto a database server using the GSM cell phone network (Dettki et al. 2004).

Using the last known GPS position followed by traditional VHF tracking, we approached the free-ranging moose directly as allowed by the terrain by one to two persons on cross-country skis that moved silent. The female moose were prime aged and we assumed all individuals to be non-naïve because they ranged at least partly, i.e., during nonparturition time, within human proximity where crosscountry skiing and other recreational activities are common.

After initial disturbance by approaching human on crosscountry skies and displacement of the moose, we performed an additional tracking for 30 min to address the impact of tracking. To study if moose habituate to disturbances, we repeated the treatments three times for each moose individual with 2 days between repetitions. To evaluate the effect of reproductive status, we included barren females $(n=3)$ as well as females accompanied by offspring $(n=6)$.

At the time and position of disturbance, we recorded temperature, precipitation type and strength, wind strength and direction, habitat data, and snow condition as well as the extent to which moose sank in relation to snow depth. To access moose perception of risk and stress level, we recorded if the moose individual fled immediately when encountered, first defecated before flight, or left calmly the position of disturbance.

\section{Data analysis}

\section{Movement activity and daily activity range}

For each moose, we calculated the distance in meters from the previous position using Euclidean distance and computed its movement rate (in meters per hour). To access individual relative moose response, we extracted the speed in the hours following disturbance and compared it with the individual's speed during the respective hour on the previous day, i.e., $24 \mathrm{~h}$ before, using Wilcoxon signed ranks test. This allowed controlling for potential effects of the moose's circadian rhythm.

To explore moose space use, we calculated diurnal activity ranges as $95 \%$ kernels (square kilometer) on the day of treatment [day 0], the 2 days before [day-2, day-1] and 1 day after treatment [day+1] using Ranges 6 v1.217 (Anatrack, Wareham, UK). We used a mixed linear model procedure with repeated statement and moose individuals as random factor using the Kenward-Roger correction to avoid type I error (Littell et al. 2006). We used adjusted $p$ values given by Tukey's post hoc test to explore the differences in diurnal activity range sizes and applied the first-order autoregressive
[AR(1)] as covariance model. We evaluated the activity ranges as fixed kernels with selected cores using least squares cross-validation inflection to estimate the smoothing factor. We used an average of $54 \pm 0.3$ standard error (SE) fixes per calculation. To test if moose left the area of disturbance, we calculated the overlap (in percent) of diurnal home ranges, as well as the distance (in meters) between the centroids of the diurnal ranges before and after treatment using Wilcoxon signed ranks test. Doing so, we compared overlap and distance between the diurnal ranges on the 2 days preceding treatment [day-2 to day-1] with the overlap and distance between the days preceding and following disturbance [day -1 to day+1], respectively. To avoid any dilution effect of earlier disturbance, we only used the first event of the experimental treatment in this analysis.

We used a mixed linear model to test which factors influenced moose movement rates following disturbances with the observed relative changes in movement rate after disturbance treatment as response variable. We allowed for negative estimates of covariance components using the [NOBOUND] option (Littell et al. 2006). We first carried out a correlation analysis on the parameters involved using Spearman's correlation coefficient $\left(r_{\mathrm{s}}\right)$. We tested the fixed factors: (1) reproductive status; (2) air temperature; (3) wind strength; (4) precipitation; (5) disturbance distance; and (6) moose initial reaction, with the three categories representing a decreasing level of impact [fled immediately; fled after defecation; calm]; (7) snow surface hardness; (8) presence of reindeer in the area; (9) moose sinking depth in snow; and (10) activity of the moose before treatment [bedding, browsing, and walking]. At the majority of the disturbance trials, 25 out of 27 moose ranged in forested habitats. The estimated average flight distance of moose approached by backcountry skiing was $160 \mathrm{~m} \pm 14$ SE. At five out of 27 disturbance trials, we observed the focal animal when approached (average flight distance $=190 \mathrm{~m} \pm$ $43 \mathrm{SE}$ ) and, for 15 of the remaining the 22 disturbance trials, we could estimate a flight distance indirectly due to directional changes in VHF signal (average flight distance $=$ $149 \mathrm{~m} \pm 12 \mathrm{SE}$ ). We explored the variance explained by the random effect moose individuals using variance component analysis (Crawley 2007). To reduce the number of parameters involved, we carried out a principal component analysis of the weather parameters and included principal components with eigenvalues $>1$. We started with a univariate model, beginning with the factors most evident from the correlation analysis and manually adding factors and their interactions to the model.

\section{Habituation}

Using a mixed linear model with repeated measures, we investigated the degree of habituation to skiing disturbance 
by comparing the observed relative changes in movement rate after treatment among the three different disturbance trials. Moose individuals were disturbed at different times of the day.

\section{Energetic locomotion costs}

We calculated the energy usage by first translating measures of moose chest circumference into body weight using the chest measure recorded during moose markings (390 kg \pm 8 SE; Wallin et al. 1996). Secondly, we estimated age for each moose by evaluating tooth wear while moose were immobilized ( 7 years $\pm 0.5 \mathrm{SE}$; Ericsson and Wallin 2001). Thirdly, we used the general formula of Taylor and Heglund (1982) to predict the energetic cost of terrestrial locomotion per unit body mass where we translated the relative moose response, i.e., change in movement rate (in meters per hour), into energetic cost to capture the energetic expenditure per kilogram body weight per time unit (in kilojoules per kilogram per hour). We tested differences of the calculated energy usages before and after treatment using the Wilcoxon signed ranks test. To evaluate energetic usage of moose calves accompanying adult females, we used as reference records the moose calves marked in the low alpine area in 2006 and 2007 (Ericsson, unpublished data). Moose calves were born the previous summer and would thereby have an age of 0.75 year at the timing of our disturbance. To address moose calves' energetic expenditures, we calculated their locomotion costs indirectly using average adult movement rates and calf body weight.

We used SAS 9.1.3 (SAS Institute, Cary, NC, USA) for all statistical analyses. Significance level was set to $p<0.05$. Data was $\log$ transformed to improve normality when needed. Average values are given with SE if not mentioned differently. We applied nonparametric tests whenever transformations failed to produce normality.

\section{Results}

Moose response was short-term, but distinct. Moose showed increased movement rates (in meters per hour) up to $3 \mathrm{~h}$ following disturbance (Fig. 2). During the first hour following disturbance, moose moved about 33 times as fast as they did during the corresponding hour on the previous day, coming along with an increase in moose energetic usage per kilogram body weight by $48 \%$ (before $3.6 \pm 0.1 \mathrm{~kJ}$ $\mathrm{kg}^{-1} \mathrm{~h}^{-1}$ versus after $5.4 \pm 0.5 \mathrm{~kJ} \mathrm{~kg}^{-1} \mathrm{~h}^{-1}, s=12, p=0.046$ ). We estimated that calves that followed adult females when disturbed would face an increase in energetic expenditures of $61 \%$. Movement rates following disturbance were correlated with snow sinking depth and with moose initial

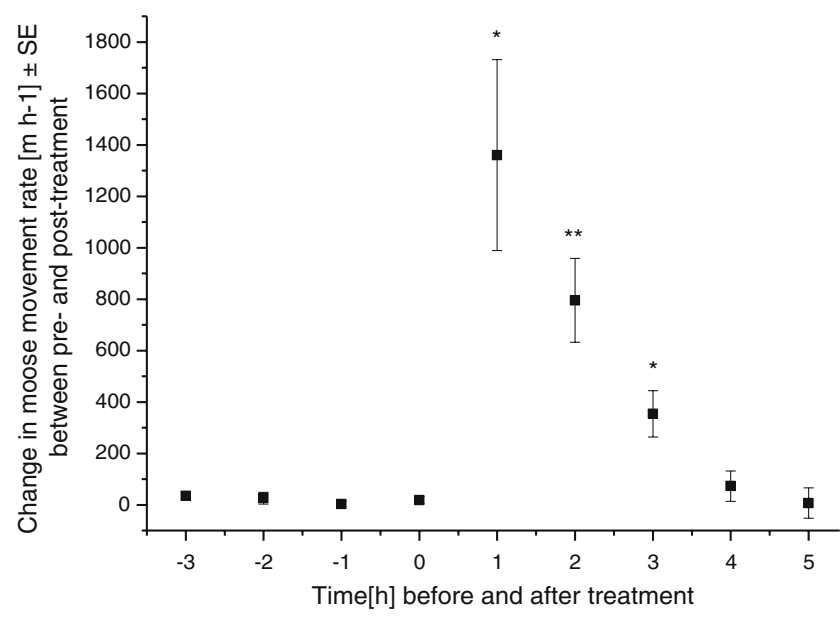

Fig. 2 Change in the average rate of moose movement (in meters per hour) \pm SE before and after skiing disturbance. ${ }^{*} p<0.05,{ }^{* *} p<0.01$, $* * * p \leq 0.0001$

reaction (sinking depth $r_{\mathrm{s}}=0.6, p=0.004$; initial reaction $\left.r_{\mathrm{s}}=-0.5, p=0.008\right)$. Individuals which increased their movement rates to the greatest extent when approached by cross-country skiers were those that responded when the skier was relatively close or those that sank deeper into snow (distance $F_{1,6}=9.5, p=0.02$; sinking depth $F_{1,4}=9.1$, $p=0.04$ ).

Moose showed no evidence of habituation to disturbance $(p=0.7)$ and the variance component analysis indicated that $36 \%$ of the variance in moose response was explained by difference among individuals.

Skiing disturbance resulted in significantly enlarged diurnal activity ranges during the day of disturbance ( 2 days before $0.05 \pm 0.03 \mathrm{~km}^{2}, 1$ day before $0.07 \pm 0.04 \mathrm{~km}^{2}$, day of disturbance $1.35 \pm 0.44 \mathrm{~km}^{2}, 1$ day after disturbance $0.04 \pm$ $\left.0.02 \mathrm{~km}^{2} ; \quad F_{3,22}=11.4, p=0.0001\right)$. Disturbance caused moose to relocate to a new area as shown by significantly less areal overlap after treatment versus before treatment (before $10 \% \pm 5$ versus after $3 \% \pm 2, s=-11, p=0.03$ ) as well as shown by the centers of moose diurnal ranges being about eight times further apart after disturbance than before disturbance with an average distance of $2,131 \pm 417 \mathrm{~m}$ compared to $256 \pm 68 \mathrm{~m}(s=22, p=0.008)$.

\section{Discussion and conclusion}

We found off-trail backcountry skiing disturbance to trigger a distinct but short-term response in moose with increased locomotion activity resulting in relocation to new area. The behavior of recreationists, predictability, frequency, and location of human activity are factors that influence the level of disturbance in wildlife (Knight and Gutzwiller 1995; Stankowich 2008). Off-trail human activity such as backcountry skiing is less predictable for wildlife than on- 
trail skiing activity and thereby bear the risk to result in a larger effect zone (Taylor and Knight 2003). Furthermore, a stimulus of unpredictable character may be more difficult to habituate to. In contrast to findings by Colman et al. (2001) for Svalbard reindeer Rangifer tarandus platyrhynchus, we did not find any evidence that moose habituated to our human-induced disturbances. We argue that the lack of habituation may be a result of the lasting human impact on moose mortality in Sweden resulting from the sustained hunting pressure in the form of high harvest rates, a long hunting season, and long period of predominance in human-related moose mortality (Ericsson and Wallin 2001; Lavsund and Sandegren 1989; Sand et al. 2006). However, we cannot exclude that the short duration of the intervals among treatments precluded the detection of habituation, although the distinct shape of changes in moose behavior when disturbed does not give strong evidences for this alternative.

We found that more than one third of the variation in moose movement rates was explained by difference among individuals. Risk assessment and degree of habituation vary among individuals in a population, and differences in behavioral responses to disturbances may be consistent for the same individuals (Picton 1999; Stankowich 2008). We suggest that greater risk perception triggered stronger response as indicated by greater movement rates in individuals that responded in shorter distance to the origin of disturbance and that sank deeper in the snow. High-risk perception as potentially experienced when tracked may highlight differences among individuals to elude the area of risk.

We found that disturbance by skiing resulted in almost a doubling of expenditures per kilogram body weight for adult moose females. Because metabolic rates are affected not only by the activity itself, but also by animal's status and vary seasonally, energetic costs of disturbances need to be considered in the context of the individual's habituation status and energetic status, which may be difficult to assess in free-ranging animals (Hudson and Christopherson 1985; Picton 1999; Schwartz and Renecker 2007). Diversity in terrain and in snow cover further complicates calculations of energy expenditures in free-ranging animals (Bunnell et al. 1990). Thus, our estimates of energy usage for increased locomotion activity, which are purely based on movement rates, reflect minimum values. Although being of shorttermed nature, such changes in energetic expenditures may be severe in areas of high human activity and for animals more sensitive in their risk perception. Moose is very well adapted to winter conditions, but especially locomotion in snow is costly and the relative cost of locomotion is higher for smaller animals as a result of their lower brisk length (Coady 1974; Fancy and White 1985; Lundmark and Ball 2008). Moose calves may, therefore, suffer even relatively higher energy costs as our estimates when moving under deep snow conditions. Furthermore, even when utilizing its mother's tracks (Coady 1974; Lundmark and Ball 2008), a calf may have difficulties in following when the female moves fast (as often done under risk avoidance) due to the female's greater stride length. Conclusively, moderate human disturbances of moose during wintertime may not be costly for adult moose per se if in good body condition, but may affect the body condition of accompanying subadults considerably, which, in turn, may affect population growth negatively.

Given that human-related disturbances are perceived analogously as a risk of predation, future research needs to address qualitatively and quantitatively the direct and indirect impacts of human activities on wildlife and to appropriately incorporate such knowledge into future wildlife and landscape management (Creel and Christianson 2007; Frid and Dill 2002; Hebblewhite et al. 2005). This is particularly needed where species are highly exposed to offtrail recreational activities and where human activities are the major source of mortality. A better understanding of the consequences is not only crucial in areas where wildlife and humans share limited space year-round (Ingold 2005), but also for areas where disturbance frequencies peak in periods that are critical for wildlife. Popularity of different recreational activities differs among time, and because off-trail activities results in a larger area of influence than on-trail activities, research needs to follow changes in tourism attitudes (Fredman and Heberlein 2003; Taylor and Knight 2003).

Acknowledgements We thank the EU/Interregional IIIA project Moose in Midscandinavia, the project Moose Management in Västerbotten, the program Adaptive Management of Fish and Wildlife, the Swedish Association for Hunting and Wildlife Management, and the Swedish Environmental Protection Agency for the financial support. We are grateful to Eric Andersson and Åke Nordström for their help with the fieldwork. We thank Nils Bunnefeld for the helpful comments. The Animal Care Committee for Northern Sweden at Umeå approved the project (Dnr A124-05 2005-11-15), which was carried out in accordance with the Swedish laws concerning animal research ethics. All personnel were certified according to the standards of the Swedish Animal Welfare Agency and the Swedish Board of Agriculture.

\section{References}

Arnemo JM, Ahlqvist P, Andersen R, Berntsen F, Ericsson G, Odden J, Brunberg S, Segerström P, Swenson JE (2006) Risk of capturerelated mortality in large free-ranging mammals: experience from Scandinavia. Wildlife Biol 12:109-113

Berger J (2007) Fear, human shields and the redistribution of prey and predators in protected areas. Biol Lett 3:620-623

Brown JS, Kotler BP (2007) Foraging and the ecology of fear. In: Stephens DW, Brown JS, Ydenberg RC (eds) Foraging: behavior and ecology. University of Chicago Press, UK, pp 437-480 
Bunnell FL, Parker KL, McNay RS, Hovey FW (1990) Sinking depths of black-tailed deer in snow, and their indices. Can J Zool 68:917-922

Cassirer EF, Freddy DJ, Ables ED (1992) Elk responses to disturbances by cross-country skiers in Yellowstone National Park. Wildl Soc Bull 20:375-381

Coady JW (1974) Influence of snow on behaviour of moose. Nat Can 101:417-436

Colman JE, Jacobsen BW, Reimers E (2001) Summer response distance of Svalbard reindeer Rangifer tarandus platyrhynchus to provocations by humans on foot. Wildlife Biol 7:275-283

Crawley MJ (2007) The R book. Wiley, England

Creel S, Christianson D (2007) Relationships between direct predation and risk effects. Trends Ecol Evol 23:194-201

Creel S, Fox JE, Hardy A, Sands J, Garrott B, Petersen RO (2002) Snowmobile activity and glucocorticoid stress responses in wolves and elk. Conserv Biol 16:809-814

Dettki H, Ericsson G, Edenius L (2004) Real-time moose tracking: an Internet based mapping application using GPS/GSM-collars in Sweden. Alces 40:13-21

Ericsson G, Wallin K (2001) Age-specific moose Alces alces mortality in a predator-free environment: evidence for senescence in females. Ecoscience 8:157-163

Fancy SG, White RG (1985) Incremental cost of activity. In: Hudson RJ, White RG (eds) Bioenergetics of wild herbivores. CRC, Florida, pp 143-160

Fortin D, Andruskiw M (2003) Behavioural response of free-ranging bison to human disturbance. Wildl Soc Bull 31:804-813

Fredman P, Heberlein TA (2003) Changes in skiing and snowmobiling in Swedish Mountains. Ann Tour Res 30:485-488

Frid A, Dill L (2002) Human-caused disturbance stimuli as a form of predation risk. Conservat Ecol 6:11

Gill JA, Norris K, Sutherland WJ (2001) Why behavioural responses may not reflect the population consequences of human disturbance. Biol Conserv 97:265-268

Hebblewhite M, White CA, Nietvekt CG, McKenzie JA, Hurd TE, Fryxell JM, Bayley SE, Paquet PC (2005) Human activity mediates a trophic cascade by wolves. Ecology 86:2135-2144

Hudson RJ, Christopherson RJ (1985) Maintenance metabolism. In: Hudson RJ, White RG (eds) Bioenergetics of wild herbivores. CRC, Florida, pp 121-142

Ingold P (2005) Freizeitaktivitäten im Lebensraum der Alpentiere. Haupt, Switzerland (In German)

Knight RL, Gutzwiller KJ (1995) Wildlife and recreationists: coexistence through management and research. Island, Washington

Lavsund S, Sandegren F (1989) Swedish moose management and harvest during the period 1964-1989. Alces 25:58-62

Liley S, Creel S (2008) What best explains vigilance in elk: characteristics of prey, predators, or the environment? Behav Ecol 19:245-254
Lima SL (1992) Life in a multipredator environment-some considerations for anti-predatory vigilance. Ann Zool Fenn 29:217-226

Littell RC, Milliken GA, Stroup WW, Wolfinger RD, Schabenberger O (2006) SAS for mixed models, 2nd edn. SAS Institute, Cary

Lundmark C, Ball JP (2008) Living in snowy environments; quantifying the influence of snow on moose behavior. Arct Antarct Alp Res 40:111-118

Picton HD (1999) Energetic cost of wildlife displacement by winter recreationists. In: Olliff T, Legg K, Kaeding K (eds) Effects of winter recreation on wildlife of the Greater Yellowstone Area: a literature review and assessment Report to the Greater Yellowstone Coordinating Committee. Yellowstone National Park, Wyoming, pp $135-144$

Reimers E, Eftestol S, Colman JE (2003) Behavior responses of wild reindeer to direct provocation by snowmobile or skier. J Wildl Manage 67:747-754

Sand H, Wikenros C, Wabakken P, Liberg O (2006) Cross-continental differences in patterns of predation: will naïve moose in Scandinavia ever learn? Proc R Soc Lond B Biol Sci 273:1421-1427

Schwartz CC, Renecker LA (2007) Nutrition and energetics. In: Franzmann AW, Schartz CC (eds) Ecology and management of the North American Moose, 2nd edn. Smithsonian Institution Press, Washington, pp 441-478

Solberg EJ, Loison A, Saether BE, Strand O (2000) Age-specific harvest mortality in a Norwegian moose Alces alces population. Wildlife Biol 6:41-52

Stankowich T (2008) Ungulate flight responses to human disturbance. A review and meta-analysis. Biol Conserv 141:2159-2173

Statistics Sweden (2008) Swedish centre for demographic data. Available at http://www.scb.se. Accessed 28 August 2008

Swedish AHWM (2009) Swedish Association for Hunting and Wildlife Management. Information about moose harvest rates. Available at http://www.jagareforbundet.se. Accessed 14 April 2009

Swedish EPA (2008) Swedish Environmental Protection Agency. Population estimates and distribution of large carnivores. Available at http://www.naturvardsverket.se. Accessed 27 July 2008

Swedish Land Survey (2008) Maps about land cover, elevation and infrastructure data. http://www.lantmateriet.se. Accessed 11 September 2008

Swenson JE, Dahle B, Busk H, Opseth O, Johansen T, Söderberg A, Wallin K, Cederlund G (2007) Predation on moose calves by European brown bears. J Wildl Manage 71:1993-1997

Taylor CR, Heglund NC (1982) Energetics and mechanics of terrestrial locomotion. Annu Rev Physiol 44:97-107

Taylor AR, Knight RL (2003) Wildlife response to recreational and associated visitor perceptions. Ecol Appl 13:951-963

Wallin K, Cederlund G, Pehrson Å (1996) Predicting body mass from chest circumference in moose Alces alces. Wildlife Biol 2:53-58 